\title{
Pseudoepitheliomatous Hyperplasia in Mycosis Fungoides
}

\author{
Mikozis Fungoideste Psödoepitelyamatöz Hiperplazi \\ Dilek BAYRAMGÜRLER ${ }^{1}$, Kürşat YILDIZ², Evren Odyakmaz DEMIRSOY ${ }^{1}$, Cengiz ERÇİN ${ }^{2}$, Rebiay KIRAN ${ }^{1}$ \\ ${ }^{1}$ Kocaeli Üniversitesi Tıp Fakültesi, Dermatoloji Anabilim Dal, , ${ }^{2}$ Patoloji Anabilim Dalı, Kocaeli
}

Submitted / Başvuru tarihi: 08.09.2008 Accepted / Kabul tarihi: 26.11.2008

\begin{abstract}
Pseudoepitheliomatous hyperplasia $(\mathrm{PEH})$ is downgrowth proliferation of the epidermis and of the adnexal structures into the dermis, mimicking a well-differentiated squamous cell carcinoma. It might be associated with many different conditions, mostly benign but rarely with some malignant conditions. Association of $\mathrm{PEH}$ with cutaneous lymphomas has occasionally been reported in the literature. Here, we report a 70-year-old man who presented with vegetative nodules clinically appearing as a tumor stage of mycosis fungoides, besides typical plaques of the disease. Histopathological examination of the tumor lesion revealed that the bulk of the tumor was due to PEH. During the follow-up period lymph node involvement was determined. We considered that mycosis fungoides cases associated with PEH should be followed up closely.
\end{abstract}

Key words: Cutaneous lymphoma; pseudoepitheliomatous hyperplasia; mycosis fungoides.
Psödoepitelyamatöz hiperplazi (PEH) epidermis ve adneksiyal yapıların iyi diferansiye skuamöz hücreli karsinomu taklit eder tarzda, alt dermise doğru proliferasyonudur. Başlıca iyi huylu nadiren de kötü huylu birçok farklı tabloya eşlik edebilir. PEH'nin kutanöz lenfomalarla ilişkisi literatürde nadiren bildirilmiştir. Burada klinik olarak mikozis fungoidesin tümör evresiyle uyumlu olan vejetatif nodüllerin yanı sıra hastalığın tipik plak lezyonlarıyla başvuran 76 yaşındaki bir erkek hasta sunulmaktadır. Tümöral lezyonların histopatolojik incelemesinde tümöral lezyonların PEH'ye bağlı geliştiği saptandı. Takip sürecinde lenf nodu tutulumu tespit edildi. PEH ile ilişkili mikozis fungoides olgularının yakın takip edilmesi gerektiğini düşündük.

Anahtar sözcükler: Kutanöz lenfoma; psödoepitelyamatöz hiperplazi; mikozis fungoides.
Mycosis fungoides (MF), which is the most common form of cutaneous lymphomas, comprises a wide clinicopathological spectrum. The majority of cases evolve clinically through the three classical stages-the patch, plaque and tumor stage; but many atypical clinical forms mimicking various inflammatory dermatoses have been reported in the literature, such as erythrodermic, follicular, syringotropic, bullous/vesicular, granulomatous, poikilodermic, hyperpigmented, hypopigmented, unilesional, palmoplantar, hyperkeratotic/verrucous, vegetating/papillomatous, ichthyosiform, pigmented purpura-like and pustular forms. This clinical diversity makes the diagnosis of MF challenging. ${ }^{[1]}$
Moreover, the histopathological diagnosis of MF can be difficult, especially in the early patch stage but also in advanced stages. ${ }^{[2]}$ There are also some unusual histological types of MF such as MF with pseudoepitheliomatous hyperplasia $(\mathrm{PEH})^{[3]}$ and pseudotumorous folliculotropic MF. ${ }^{[4]}$ These patients present with exophytic scaling plaques, nodules ${ }^{[4]}$ or seborrhoeic keratosis-like lesions. ${ }^{[3]}$ These unusual clinical and histopathological types can cause problems either during the diagnosis or in staging of patients with MF.

\section{CASE}

A 70-year-old man was referred to our outpatient clinic for the evaluation of extensive, erythematous and 
scaling lesions. He reported that he had been followed with the diagnosis of psoriasis for the last 15 years. Initial dermatological examination revealed 1-5 cm, erythematous, scaling, slightly infiltrated plaques on his scalp, trunk and extremities. Four vegetative tumors, $1-2 \mathrm{~cm}$ in diameter on his right limb were also noticed (Figure 1).

In the axillary and inguinal regions, several palpable, mobile lymph nodes with an average dimension of $1 \mathrm{~cm}$ were also determined bilaterally by ultrasound evaluation. Laboratory examinations, including total blood count, renal and hepatic function tests, lactate dehydrogenase, magnesium, eosinophilic cationic protein and immunoglobulin E levels were within normal ranges. On peripheral blood smear no atypical leucocytes were seen. There were no pathological findings on abdominal and thoracic tomography.

Histopathologic examination of the biopsy specimen taken from plaque lesions revealed parakeratosis, psoriasiform acanthosis and marked epidermotropism with perivascular mononuclear cell infiltration in the dermis. Immunhistochemical stains were carried out and showed cytoplasmic positivity for CD3, CD4 and CD5 antibodies. There was no reaction for CD7, CD8 and CD30 antibodies in the neoplastic lymphoid cells. Expression of the cytotoxic enzymes perforin and granzyme A was also negative. Histopathological examination of the tumoral lesion showed intense atypical lymphocyte infiltration of the epidermis. The epidermis showed branching rete with excessive irregular hyperplasia (PEH) (Figure 2) and these findings were interpreted as pseudoepitheliomatous hyperplasia. Biopsy of an axillary lymph node showed no pathologic findings. Based on these clinical, histopathological and other laboratory findings,our patient was diagnosed as MF stage IIa and therapy was given with psolaren plus ultraviolet A (PUVA) (3 times weekly) in combination with acitretin (25mg/day). Within 5 months, the erythematous plaque lesions had cleared significantly and tumor lesions healed with atrophic scars (Figure 3). Then the patient was lost to follow up. One year later, the patient returned to our clinic with infiltrated, scaly erythematous plaques on the extremities and trunk. Atrophic scars were present at the site of previous tumor lesions. Hematological and biochemical tests, thoracic and abdominal tomography revealed no pathologic findings. There was enlargement in the axillary lymph nodes on lymph node ultrasound (nearly $2 \mathrm{~cm}$ ). Biopsy of a lymph node showed atypical lymphoid aggregates in the paracortical zone with CD3 (+) immune reaction and positivity with CD45 $\mathrm{RO}$ antigen. On the other hand, the CD20 stain was negative. It was accepted as lymph node involvement and the patient was graded as stage IVa. Subcutaneous interferon alpha therapy was planned.

\section{DISCUSSION}

$\mathrm{PEH}$, also known as pseudocarcinomatous hyperplasia, is a benign proliferation of the epidermis and of the adnexeal structures into irregular squamous strands extending down to the dermis. It is almost always associated with persistent inflammation of the subjacent dermis due to chronic wounds and ulcers, chronic infections of the skin, soft tissue or bone, retained foreign materials, inflammatory dermatosis such as hypertrophic lichen planus, benign neoplasm such as granular cell tumor or malignancies such as melanoma and lymphoma. Lesions with PEH often present clinically with verrucous or multinodular lesions. ${ }^{[5]}$

$\mathrm{PEH}$, has occasionally been reported in the literature as a manifestation of cutaneous lymphomas. It has been associated especially with CD30+ anaplastic large cell lymphoma in the majority of cases ${ }^{[3,4,6]}$ and rarely with lymphomatoid papulosis type $\mathrm{A}^{[6]}$ and $\mathrm{MF}^{[3,4]}$

The first comprehensive study describing the clinical and histopathological features of PEH in cutaneous T-cell lymphomas was reported by Courville et al. in 1999, although this particular association had rarely been reported previously. ${ }^{[7,8]}$ The authors studied 11 cases with PEH which were collected from a series of 353 cutaneous lymphomas registered between 1990 and 1996 by the French Study Group of Cutaneous Lymphomas in their study. They found that all of the cases associated with PEH were of T-cell-lineage; 8 cases were associated with $\mathrm{CD} 30+$ large $\mathrm{T}$-cell lymphomas and 3 with MF. They reported the incidence of this particular presentation as $28.5 \%$ in CD30+ large T-cell lymphomas and $2 \%$ in MF. The clinical presentation of MF patients was described as tumor stage, plaque stage and leukemia stage, respectively. They noted that skin lesions of the $2 \mathrm{MF}$ patients had mimicked seborrhoeic keratoses. Systemic evaluation of these patients revealed localised nodal involvement in one and bone marrow infiltration in the other patient with a mean duration of 17 months of survival.

Then, Kossard and Weller reported an 85-year-old man with pseudotumorous folliculotropic MF. Their patient presented clinically with progressive, exophytic, scaling plaques and nodules on his extremities, trunk and scalp for the previous 2 years. Skin biopsies taken from these nodules revealed a marked follicular hyperplasia as a result of folliculotropic MF. They treated the patient with acitretin and prednisolone with a marked improvement but he died after 2 months due to an unknown cause. The authors explained that although clinical examination of their patient was compatible with advanced tumor stage of MF, the histopathological examination was not compatible with the advanced stage; the bulk of his nodules were due to follicular hyperplasia. ${ }^{[4]}$ 
Another study about this particular association was reported by Scarisbrick et al. In this study 3 patients with CD30+large cell anaplastic lymphoma and 3 patients with lymphomatoid papulosis with histologic evidence of PEH were described. Initial clinicopathologic diagnosis was squamous cell carcinoma in 4 of these patients and eruptive keratoacanthoma in 1 patient. The authors concluded that $\mathrm{PEH}$ associated with CD30+ lymphoproliferative diseases may closely resemble squamous cell carcinoma, leading to inappropriate diagnosis and treatment. ${ }^{[6]}$ The mechanism of PEH is unknown. It is speculated that inflammatory cytokines or growth factors released by dermal inflammatory cells or tumor cells stimulate the proliferative growth of the epidermis. ${ }^{[5]}$ To test this hypothesis in cutaneous $\mathrm{T}$ cell lymphomas, Courville et al. studied the epidermal growth factor (EGF), EGF receptor (EGFr) and transforming growth factor-alpha (TGF- $\alpha$ ) expressions in their patients. They found that epidermal expression of EGF, EGFr and

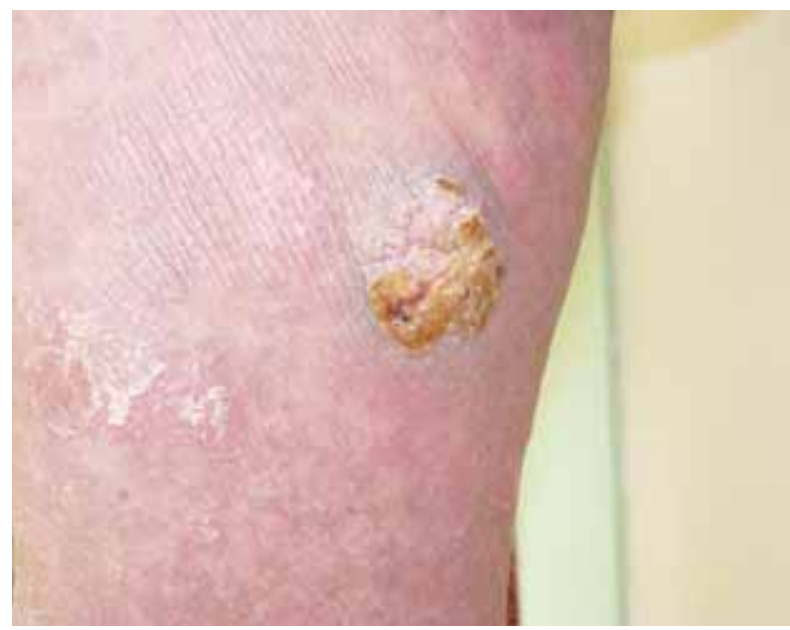

Figure 1. Erythematous, scaling, slightly infiltrated plaques and a vegatative tumor on the right thigh.

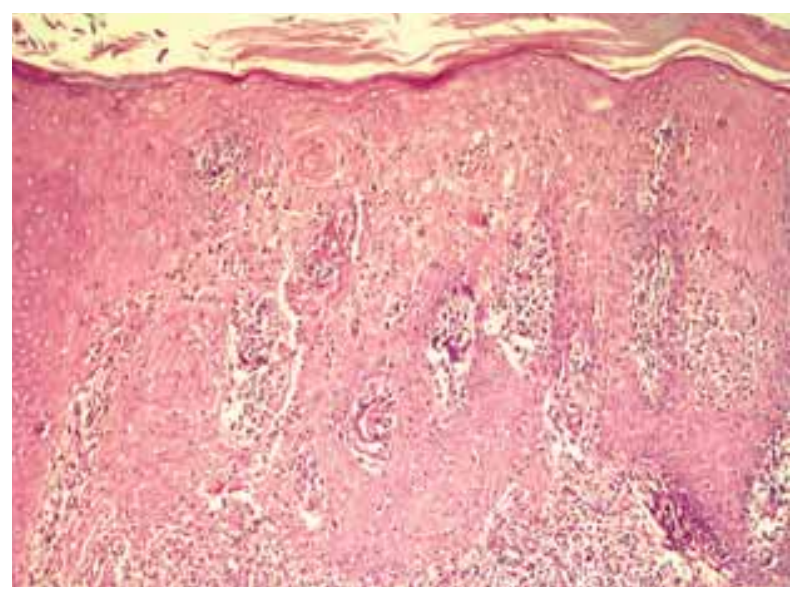

Figure 2. Intense atypical lymphocyte infiltration that infiltrated branching rete with excessive irregular hyperplasia (pseudoepitheliomatous hyperplasia) in epidermis.

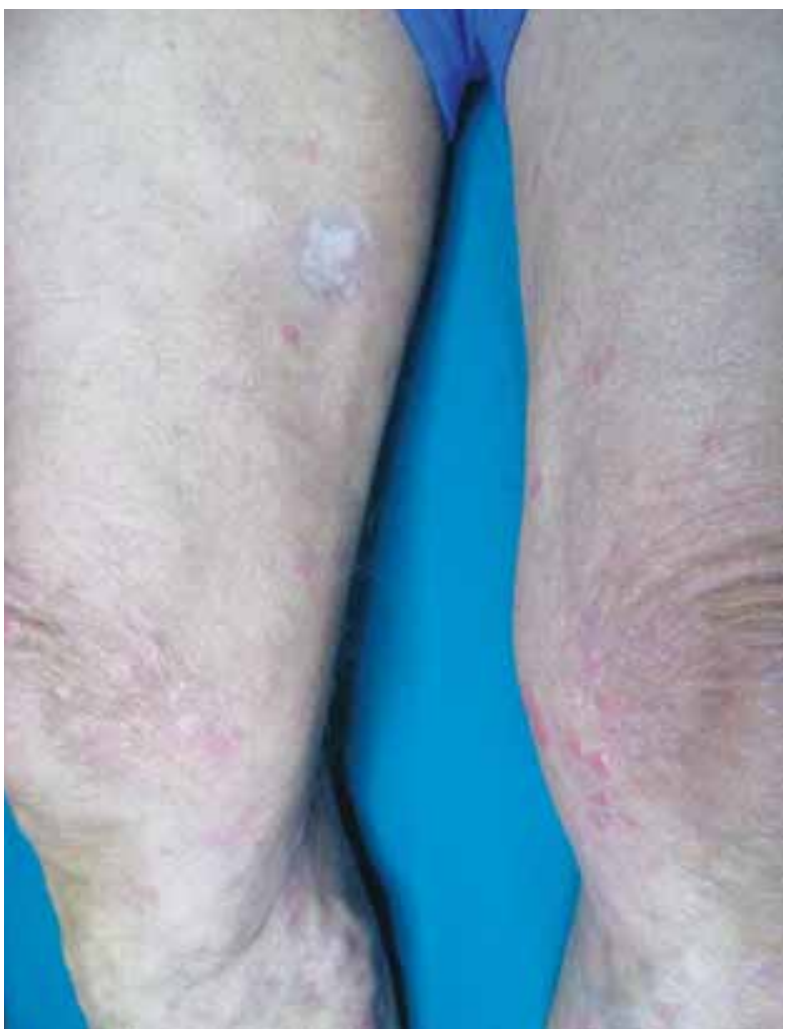

Figure 3. The appearance of the lesions after 1 year of treatment.

TGF- $\alpha$ was stronger in cutaneous $\mathrm{T}$ cell lymphoma cases when compared to normal human skin; and epidermal expression of EGFr was stronger in cutaneous T cell lymphoma cases with PEH when compared with the cases of cutaneous $\mathrm{T}$ cell lymphoma without $\mathrm{PEH}$. They also showed that lymphomatous $\mathrm{T}$ cells in their patient group expressed an aberrant EGF and TGF- $\alpha$ expression when compared with cutaneous and nodal B cell lymphomas and normal lymph nodes. The authors concluded that these cytokines were probably involved in PEH observed in some cases of cutaneous T cell lymphoma. ${ }^{\left[{ }^{3]}\right.}$ On the other hand, Scarisbrick et al. reported that there was no aberrant expression of EGF, EGFr and TGF- $\alpha$ in either epidermis or atypical lymphocytes compared with adjacent normal epidermis. ${ }^{[6]}$

In conclusion, our patient presented with a few large, vegetative nodules that clinically appeared as the tumor stage of MF along with typical plaque lesions of MF. In contrast, the findings of histopathological examination of tumor lesions were not compatible with tumor stage of MF but rather revealed that the bulk of his nodule was due to a marked PEH. In previous cases, PEH has been associated with nodal involvement in one and bone marrow infiltration in the other. ${ }^{[3]}$ The mean survival for these patients was 17 months. Although the stage of our patient was IIa at the time of diagnosis, within a year, he progressed to stage VIa, with axillary lymph node involvement. The prognostic implication of PEH in MF 
remains unclear, but at the very least, MF patients who demonstrate $\mathrm{PEH}$ in their biopsies deserve close clinical follow-up and monitoring for disease progression. $\mathrm{PEH}$ may portend a poor prognosis whatever stage the patient is in.

\section{Conflict of Interest}

No conflict of interest declared by the authors.

\section{REFERENCES}

1. Kazakov DV, Burg G, Kempf W. Clinicopathological spectrum of mycosis fungoides. J Eur Acad Dermatol Venereol 2004;18:397-415.

2. Glusac EJ. Criterion by criterion, mycosis fungoides. Am J Dermatopathol 2003;25:264-9.

3. Courville P, Wechsler J, Thomine E, Vergier B, Fonck Y, Souteyrand $\mathrm{P}$, et al. Pseudoepitheliomatous hyperplasia in cutaneous T-cell lymphoma. A clinical, histopathological and immunohistochemical study with particular interest in epithelial growth factor expression. The French Study Group on Cutaneous Lymphoma. Br J Dermatol 1999;140:421-6.

4. Kossard S, Weller P. Pseudotumorous folliculotropic mycosis fungoides. Am J Dermatopathol 2005;27:224-7.

5. Lynch JM. Understanding pseudoepitheiomatous hyperplasia. Pathology case reviews 2004;9:36-45.

6. Scarisbrick JJ, Calonje E, Orchard G, Child FJ, RussellJones R. Pseudocarcinomatous change in lymphomatoid papulosis and primary cutaneous CD30+ lymphoma: a clinicopathologic and immunohistochemical study of 6 patients. J Am Acad Dermatol 2001;44:239-47.

7. Krasne DL, Naritoku WY, Cosgrove MM. Diagnosis of syncytial (lacunar cell-predominant) nodular sclerosing Hodgkin's disease by fine needle aspiration. A case report. Acta Cytol 1993; 37:418-22.

8. Krishnan J, Tomaszewski MM, Kao GF. Primary cutaneous CD30-positive anaplastic large cell lymphoma. Report of 27 cases. J Cutan Pathol 1993;20:193-202. 